$A N L-C T--83-6$

DE84 001022

ARGONNE NATIONAL LABORATORY

9700 South Cass Avenue

Argonne, Illinois 60439

\title{
INTERIM REPORT ON THE STATE-OF-THE-ART OF SOLID-STATE MOTOR CONTROLLERS. \\ PART 4. FAILURE-RATE AND \\ FAILURE-MODE DATA \\ by
}

R. A. Jaross

Components Technology Division

September 1983

Prepared for

U. S. Nuclear Regulatory Commission Office of Nuclear Regulatory Research Division of Facility Operations Washington, D. C.. 20555 


\section{DISCLAIMER}

This report was prepared as an account of work sponsored by an agency of the United States Government. Neither the United States Government nor any agency thereof, nor any of their employees, makes any warranty, express or implied, or assumes any legal liability or responsibility for the accuracy, completeness, or usefulness of any information, apparatus, product, or process disclosed, or represents that its use would not infringe privately owned rights. Reference herein to any specific commercial product, process, or service by trade name, trademark, manufacturer, or otherwise does not necessarily constitute or imply its endorsement, recommendation, or favoring by the United States Government or any agency thereof. The views and opinions of authors expressed herein do not necessarily state or reflect those of the United States Government or any agency thereof. 


\section{CONTENTS}

\section{Page}

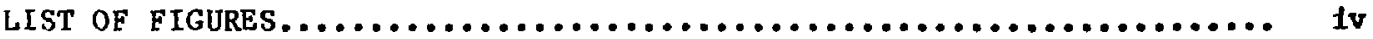

LIST OF TABLES...................................... Iv

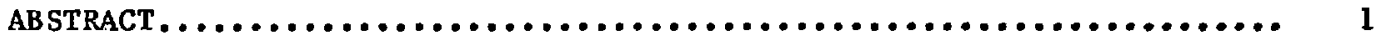

EXECUTIVE SUMMARY $\ldots \ldots \ldots \ldots \ldots \ldots \ldots \ldots \ldots \ldots \ldots \ldots \ldots \ldots \ldots \ldots \ldots \ldots \ldots \ldots \ldots \ldots \ldots$

1. INTRODUCTION. ................................... 2

2. NUCLEAR POWER PLANT INVERTER EXPERIENCE AS A BASIS

FOR SSMC RELIABILITY ESTIMATION........................ 3

2.1 NRC Inverter Fallure Assessment..................... 3

2.2 BNL Unpublished Data............................. 3

2.3 Nuclear Safety Analysis Center Data..................... 9

2.4 Summary of Inverter Rellability Estimates Based on LERs..... 10

3. RELIAB ILITY OF LARGE LOAD-COMMUTATED-INVERTER

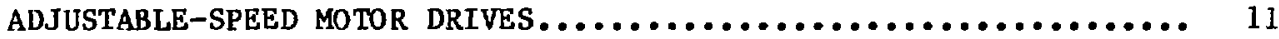

3.1 General Electric Drive System...................... 12

3.2 Westinghouse Drive System......................... 14

4. HIGH-VOLTAGE DC TRANSMISSION-LINE CONVERTER

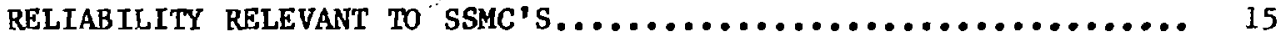

5. SUMMARY ......................................... 19

REFERENCES.......................................... 21 


\section{F IGURES}

Figure

Page

1 Major Components in a Typical ICPS Configuration...........

\section{TABLES}

Table

Page

1 Inverter Failure Causes in 17 Selected PWRs

Totalling 97 Reactor-Years of Experience................. 4

$2 \quad$ Vital-Bus Inverter Subcomponents..................... 6

3 Causes of Random Failures of Inverter Subcomponents in

Nuclear Power Plants, December 1972 through March 1983...... 7

$4 \quad$ Causes of Nonrandorn Inverter Subcomponents Failure in

Nuclear Power Plants, December 1972 through March 1983...... 8

5 Percentage Distribution of Categorized Failures............ 10

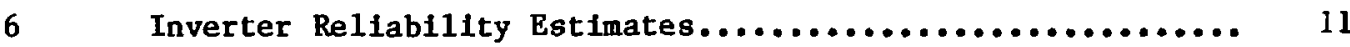

7 GE Load-Commutated-Inverter System Subcomponent

Categories, Failure Rates, and Availability.............. 13

8 Worldwide Solid-State High-Voltage DC Transmission

Systems, 1979-1980.................................. 16

9 Component Fallues Causing HVDC System Outages

in $1979-1980 \ldots \ldots \ldots \ldots \ldots \ldots \ldots \ldots \ldots \ldots \ldots \ldots \ldots \ldots \ldots \ldots \ldots \ldots \ldots \ldots . \ldots \ldots 17$

10 Thyristor Failure Rates in HVDC Systems................. 19

11 Summary of Solid-State System Reliabllity............... 20 
INTERIM REPORT

ON THE STATE-OF-THE-ART OF SOLID-STATE MOTOR CONTROLLERS: PART 4 - FAILURE RATE AND FAILURE MODE DATA

ABSTRACT

An assessment of the reliability of solid-state motor controllers for nuclear power plants is made. Available data on fallure-rate and fallure-mode data for solid-state motor controllers based on industrial operating experience is meager; the data are augmented by data on other solid-state power electronic devices that are shown to have subcomponents similar to those found in solid-state motor controllers. In addition to large nonnuclear solid-state adjustable-speed motor drives, the reliability of nuclear plant inverter systems and high-voltage solid-state dc transmission-line converters is assessed. Licensee Event Report analyses from several sources, the open literature, and personal communications are used to determine the reliability of solid-state devices typical of those expected to be used in nuclear power plants in terms of failures per hour.

EXECUTIVE SUMMARY

As part of a program to assess the use of solid-state motor controllers in commerclal nuclear power plants, the development of a reliability data base using industrial experience is warranted. Our investigations showed that there is no organized and consistent reporting system on the rellability of solid-state motor controllers in Industrial applications and there is very limited use of solid-state motor controllers in nuclear power plants. There was, therefore, no possibility of using the monthly utility-generated Licensee Event Reports directly as a source of fallure data on solid-state motor controllers. It was possible, however, to use the Licensee Event Reports indirectly by studying the failures of the widely used solid-state inverters, which supply uninterruptible power to vital-1nstrument busses. All subcomponents of these static inverters are found in solid-state motor controllers and are susceptible to the same failure modes.

The reliability of inverters used in nuclear power plants was studied using References 1, 2, and 3. Our assessment of these sources indicates that for periods between 1972 and 1983 and for an experience base of as many as 2644 inverter-years, the failure rate was in the range of 1 to $2 \times 10^{-5}$ failures/hour.

In the development and use of large-load commutated-inverter adjustable- 
speed motor drives, both General Electric and Westinghouse have estinated the rellabllity of such motor drives based on experience with subcomponents but have not complled reliability data on complete units. The solid-state motor controllers range up to $17,500 \mathrm{hp}$ in slze and have a calculated reliability of from 5 to $12 \times 10^{-5}$ rallures/hour and avallabilities of 99.9\%. Reliability in these units can be enhanced greatly by the use of redundant and parallel subsections.

A very well-organized system for collection of reliability data on highvoltage dc transmission-line converters exists worldwide. Ten transmission systems using solid-state converters of 320-1920 MW each were assessed for the perlod 1979-1980. Unit reliability was found to be $51.2 \times 10^{-5}$ failures per hour and avallability $99.0 \%$. Redundancy is not reflected in this design.

It is evident from the data that size and complexity of solid-state devices play a very large part in determining their rellability, and that the solid-state semiconductors themselves are only a minor contributor to the total failure rate.

\section{INTRODUCTION}

Solid-state motor controllers are being considered by industry for use in nuclear power plants. A solid-state motor controller (SSMC) is a device composed of electronic components (e.g., integ rated circuits, microcomputers, fiber optics, high-power transistors, and silicon-controlled rectifiers) arranged to control the starting, stopping, operating, and fault characteristics of $A C$ and $D C$ motors, and maintain them safely within their design parameters. The purpose of the project for which this report is being written is to investigate the use of solid-state motor controllers in nuclear power plants to determine whether their use would be acceptable from a regulatory standpoint.

This interim report covers work performed since the initiation of the program at Argonne National Laboratory in March 1983. It covers Task 2.2.1 of the Statement of Work: "Compile fallure rate and fallure mode data base for solid-state motor controllers and associated circuits for use in est Imating their rellability." The specific objective is to determine if SSMCs currently on the market are sufficiently rellable for use in safety systems in nuclear 
power plants.

\section{NUCLEAR POWER PLANT INVERTER EXPERIENCE AS A BASIS FOR SSMC RELIABIJITY ESTIMATION}

Although there is only very limited evidence of the use of solid-state motor controllers (SSMCs) in nuclear power plants, we have estimated probable failure rates of these devices should they be so employed. In dealing with SSMCs, fallure rates generated from computer, microprocessor and instrumentation and control equipment experience may be of limited value due to the much-lower power ratings of these components. We have sought instead to learn from the experfence gained on heavier-duty solid-state devices presently used in nuclear power plants. Although they are not motor controllers, devices such as battery chargers and inverters

Are of sufficiently high power to be of interest,

Use many of the subcomponents found in SSMCs, and

Are presently used in nuclear power plants in safety-related, class

IE applications, including vital-instrument bus-power supplies and diesel-generator field supplies and controls.

Because failure data on these systems appear in the Licensee Event Reports (LERs), they are a good source of rellable data on utility experience with highly qualified, well-maintained equipment of a type very similar to SSMCs.

\subsection{NRC INVERTER FAILURE ASSESSMENT}

A summary of inverter failures $[1]^{*}$ indicates that in the seven years up to $2 / 11 / 81$ there had been 186 inverter failures from all causes reported in operating nuclear power plants. Of these, 118 have been in PWRs, 64 in BWRs and 4 in HTGRs. Of particular significance was a group of 17 PWRs, representing $\sim 97$ reactor-years of operation, that have experienced 46 inverter fallures resulting in 40 reactor trips and/or 20 safety injections. Assuming 4 inverters per plant, this would indicate an inverter failure rate of 0.118 inverters per reactor-year, or $1.35 \times 10^{-5}$ failures/hr. Of this same group of 17 PWRs, the total number of reactor trips from all equipment fallure causes for the same time period was $~ 344$. Therefore, inverter fallures alone caused $\sim 12 \%$ of the total number of reactor trips during this time period in this group of PWRs. The causes for the 186 inverter fallures in the group of 17 PWRs are shown in Tabie 1.

\subsection{BNL UNPUBLISHED DATA}

A wore thorough evaluation of inverter failures was conducted by Brookhaven National Laboratory (BNL) using LERs from December 1972 to December 1981 and other Nuclear Safety Information Center (NSIC) data [2]. The BNL data were updated by ANL using LERs appearing in the monthly compllation

\footnotetext{
*Numbers in brackets [ ] are reference numbers.
} 
Table 1. Inverter Fallure Causes in $1^{7}$ Selected PWRs Totalling 97 Reactor-Years of Experience

\begin{tabular}{|c|c|}
\hline Failure Cause & Number of Incldents \\
\hline Unidentifled cause & 40 \\
\hline Current/voltage surges & 22 \\
\hline Human error & 20 \\
\hline Capacitor & 17 \\
\hline Silicon controlled rectifler & 9 \\
\hline Input voltage trip & 6 \\
\hline Diode & 7 \\
\hline Excess amblent temp. & 6 \\
\hline Constant voltage transformer & 5 \\
\hline Mechanical & 4 \\
\hline Oscillator card & 3 \\
\hline Transistor & 3 \\
\hline Transformer & 3 \\
\hline Circuit board & 3 \\
\hline Relay & 3 \\
\hline Faulty components & 2 \\
\hline Frequency card & 2 \\
\hline$A C / D C$ protection card & 2 \\
\hline Choke & 2 \\
\hline Res istor & 5 \\
\hline Design $w / 0$ auto transfer & 2 \\
\hline Fan motor & 1 \\
\hline Output filter & 1 \\
\hline Driver sync. board & 1 \\
\hline Master $\log 1 \mathrm{c}$ board & 1 \\
\hline Gate driver board & 4 \\
\hline Dirty circuits & 1 \\
\hline Local components overheat ing & 1 \\
\hline Control module & 7 \\
\hline clock card & 1 \\
\hline Power supply & 2 \\
\hline
\end{tabular}

reports from January 1982 through March 1983. The inverter failures considered included only those inverters assoclated with the $120-\mathrm{V}$ ac vital-power systems supplying uninterruptible power to lnstruments and controls. The dc input to the inverters and the switchgear on the $120-\mathrm{V}$ ac vital busses was not considered.

In most modern nuclear plants, 4 channels of uninterruptible power using an inverter in each are assigned among 2 or 4 instrument divisions. In older plants where high-rated Inverters were not avallable, "master" and "slave" inverters frequently were used in parallel to achieve the required load remand. 
During the last 10 years the design of the inverters has changed significantly. Four basic inverter desigus currently are in use:

The ferroresonant transformer,

The quasisquare wave,

The pulse-width modulated, and

The step wave.

Although inverter designs yary greatly and are essentially "custon made" for Class 1E applications, certain basic similarities in design allow for allocation of specific failures to individual subcomponents. In general, the 120-V ac vital-bus inverters are composed of subcomponents, many of which are found in prototypic SSMCs. The inverter subcomponents are described in Table 2. 
Table 2. Vital-Bus Inverter Subcomponents

\begin{tabular}{|c|c|}
\hline Subcomponent & Funct ion \\
\hline Input circuit breaker & Interrupts high instantaneous input currents. \\
\hline Over/under voltage detector & $\begin{array}{l}\text { Monitors safe range of input voltage and pre- } \\
\text { vents danage due to large transients through } \\
\text { DC input filter (see below). }\end{array}$ \\
\hline Reverse polarity detector & $\begin{array}{l}\text { Prevents fatled inverter from loading by its } \\
\text { assoclated normal or energency power source. }\end{array}$ \\
\hline dc input filter & $\begin{array}{l}\text { Protects dc lines from inverter-generated } \\
\text { noise and protects inverter from unwanted } \\
\text { modulation harmonics and excessive voltage } \\
\text { spikes. }\end{array}$ \\
\hline $\begin{array}{l}\text { dc/ac inverter module } \\
\text { Thyristors (SCRs) }\end{array}$ & $\begin{array}{l}\text { Usually several bridge-connected units working } \\
\text { together; firing pulse is applied to alternate } \\
\text { pairs in each bridge by the drive nodule (see } \\
\text { below). }\end{array}$ \\
\hline $\begin{array}{l}\text { Commutator/voltage surge } \\
\text { suppression and snubber } \\
\text { capacitors }\end{array}$ & $\begin{array}{l}\text { Protect against conmutation fallure, over-load } \\
\text { currents, and voltage changes and out-of-phase } \\
\text { load currents. }\end{array}$ \\
\hline Diodes and fuses & $\begin{array}{l}\text { Additional protection against overcurrent and } \\
\text { voltage changes. }\end{array}$ \\
\hline Drive module & $\begin{array}{l}\text { Provide gating currents for all SCRs. Gener- } \\
\text { ally contain as many amplifiers and output } \\
\text { channels as there are sCRs. Amplifiers form } \\
\text { the approprlate shape and magnitude of gating } \\
\text { pulses obtained from the oscillator/ } \\
\text { synchronizer module (see below). }\end{array}$ \\
\hline $\begin{array}{l}\text { Oscillator and synchronizer } \\
\text { module }\end{array}$ & $\begin{array}{l}\text { Determines operating frequency of inverter and } \\
\text { directs sequence pattern of driving pulses and } \\
\text { regulates their phases. }\end{array}$ \\
\hline Internal power supply & $\begin{array}{l}\text { Provides power to drive midule, oscillator and } \\
\text { synchronizer module; usually of conventional } \\
\text { design. }\end{array}$ \\
\hline $\begin{array}{l}\text { Harmonic reduction } \\
\text { transformer }\end{array}$ & $\begin{array}{l}\text { Ferroresonant transforner used in ear'y } \\
\text { inverters to decrease unwanted harmonics. }\end{array}$ \\
\hline filter & $\begin{array}{l}\text { Improves sine-wave } \\
\text { reactive elements. }\end{array}$ \\
\hline $\begin{array}{l}\text { Regulation and control } \\
\text { module }\end{array}$ & $\begin{array}{l}\text { Compares ac output voltage with stable } \\
\text { reference voltage and applies the error signal } \\
\text { to the drive module and/or synchronizing } \\
\text { module. }\end{array}$ \\
\hline $\begin{array}{l}\text { Output circuit breaker/static } \\
\text { transfer }\end{array}$ & $\begin{array}{l}\text { Protects against load shorts and overloads } \\
\text { automatic recovery feature. }\end{array}$ \\
\hline
\end{tabular}


Random fallures, defined as those due to wear-out or failure of properly operated subcomponents, constitute the major source of plant inverter fallures. Table 3 lists these subcomponents together with other specialized and miscellaneous components and gives the number of failure events reported for each in LERs between December 1972 and March 1983.

Table 3. Causes of Random Fallures of Inverter Subcomponents in Nuclear Power Plants, December 1972 through March 1983

\begin{tabular}{lc}
\hline Subcomponent & Number of Failures \\
\hline Input circuit breaker & 1 \\
Over/under voltage and reverse polarity detector & 9 \\
dc input filter & 4 \\
dc/ac inverter module & 11 \\
SCRs & 3 \\
Commutator/surge suppression/snubber capacitors & 7 \\
Diodes and fuses & 10 \\
Drive module & 13 \\
Oscillator and synchronizer module & 7 \\
Internal power supply & 6 \\
Harmonic reduction transformer & 16 \\
Output filter & 11 \\
Regulation and control module & 10 \\
Output circuit breaker/static transfer & 6 \\
Unidentified subcomponents & 12 \\
Capacitors & 9 \\
Fuses & 26 \\
Mechanical failures & 5 \\
Failures due to unknown causes & 166 \\
Auxiliary transformers & \\
Total random failures & \\
\hline
\end{tabular}

In addition to random failures, several other categories of fallure have been considered in analyzing the LER data:

Environmental effects include conditions that are incompatible with normal use, such as high temperature, high humidity, dirt, IIghtning, fire, etc.

Miscellaneous external failures involve failures whose cause have sone common character, such as design error, manufacturing or installation fallure, or incorrect operating instrumention or procedure.

Human errors include failures caused by the plant personnel in normal operation or maintenance.

Transient fallures are those unavoidable instances where the inverter is tripped correctly in response to varlous transients with no failed subcomponent resulting from the cause of the trip. 
These nonrandom fallures are further subdivided as shown in Table 4; also shown are the number of fallure events reported for each in LERs in the same time period as those for the random failures in Table 3 and the percent of total represented by each subcategory.

Table 4. Causes of Nonrandom Inverter Subcomponent Fallure in Nuclear Power Plants, December 1972 through March 1983

\begin{tabular}{|c|c|c|}
\hline \multirow[t]{2}{*}{ Failure Mode } & \multicolumn{2}{|c|}{ Failures } \\
\hline & Number $(\%$ of & Tota1) \\
\hline \multicolumn{3}{|l|}{ Environmental effects } \\
\hline High ambient temperature, low ventilation & 15 & \\
\hline Lightning & 5 & \\
\hline $\begin{array}{l}\text { Dirt, foreign material } \\
\text { Subtotal }\end{array}$ & $\frac{2}{20}(7 \%)$ & . \\
\hline \multicolumn{3}{|l|}{ Miscellaneous external fallures } \\
\hline Design fallure & 4 & \\
\hline Manufacturing/Anstallation failure & 3 & \\
\hline Incorrect instruction & 1 & \\
\hline Subtotal & $\overline{8}(3 \%)$ & \\
\hline \multicolumn{3}{|l|}{ Human error } \\
\hline Operation-related & 25 & \\
\hline Maintenance-related & 23 & \\
\hline Installation testing & 1 & \\
\hline Procedure-related & 2 & \\
\hline Subtotal & $\overline{51}(19 \%)$ & \\
\hline \multirow{2}{*}{$\begin{array}{l}\text { Transient failures } \\
\text { Voltage/current transients resulting } \\
\text { in open breakers/fuses }\end{array}$} & & \\
\hline & $29(11 \%)$ & \\
\hline Total nonrandom failures & $\overline{108}$ & \\
\hline \multirow{2}{*}{$\begin{array}{l}\text { Total random failures } \\
\text { (from Table } 3 \text { ) }\end{array}$} & $166(60 \%)$ & \\
\hline & $274(100 \%)$ & \\
\hline
\end{tabular}

The number of random inverter failures $\left(N_{r}=166\right.$, from Table 3$)$ is an indication of the quality of the custom-made inverters to be found in nuclear plants and is a strong guide to the performance that could be expected from SSMCs. The total number of failures shown in Table $4\left(\mathrm{~N}_{\mathrm{T}}=274\right)$ characterizes the availability and risk of inverters operating in a nuclear plant environment. Unfortunately, the LERs do not provide information about the time spent for repairs, so it is not possible to estimate the true avallabllity of the inverters based on these reports. 
The number of reactor-years of operating experience between December 1972 and March 1983 is estimated to be 661 reactor-years. Assuming four $120-\mathrm{V}$ ac vital-bus inverters per plant for a total experience of 2644 inverter-years, the fallure rates $(\lambda)$ are:

$$
\lambda(\text { random })=\frac{166 \text { (Inv. failures) }}{2644 \times 9760 \text { (1nv. hr })}=0.717 \times 10^{-5} \text { failures } / \mathrm{hr}
$$

and

$$
\begin{aligned}
\lambda(\text { total })=\frac{274}{2644 \times 8760} & =1.18 \times 10^{-5} \text { failures } / \mathrm{hr} \\
& =0.104 \text { failures } / \mathrm{yr} .
\end{aligned}
$$

\subsection{NUCLEAR SAFETY ANALYSIS CENTER DATA}

A third study of inverter fallures was conducted by the Nuclear Safecy Analysis Center of the Electric Power Research Institute [3]. In assessing I\&C power supply hardware, the study showed that inverters were the leading cacise of failure. The study detailed 181 reported failures, based again on LERs, but included (in addition to inverters) components of I\&C power supplies other than just those associated with the $120-\mathrm{V}$ ac vital instrument busses. In our analysis of this study, to obtain a fallure rate we have determined the rate both with and without the non-inverter components included. Thus we consider the total I\&C power supply, as shown in Figure 1 , and the inverter only.

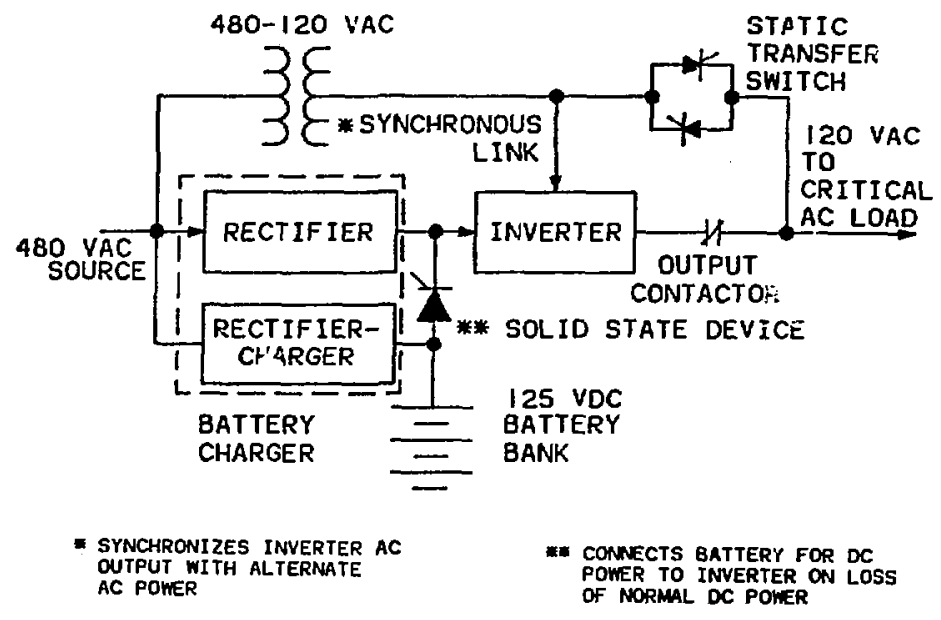

Fig. 1. Major Components in a Typical ICPS Configuration.

The typical I\&C power supply has components that, except for the battexy, can be found in most SSMCs. Unfortunately, the battery or battery charger is the chief fallure source outside the inverter, hence our decision to consider both total I\&C power supplies and inverters only. 
Categorization of the failures in a manner similar to that used in Reference 2, both with and without battery related fallures (29 of a total of 181 fallures), results in the percentage distribution of failures shown in Table 5. The percentages of fallures within these categorles compare favorably with those given in Reference 2.

Table 5. Percentage Distribution of Categorized Failures

\begin{tabular}{lcc}
\hline Fallure Category & $\begin{array}{c}\text { \%, Based on } \\
\text { Total }\end{array}$ & $\begin{array}{c}\text { \%, Based on Total } \\
\text { Less }\end{array}$ \\
\hline Battery Fallures
\end{tabular}

Reference 3 listed 181 failures in 50 different nuclear plants in the time period 1977-1981. Our estimate of the total reactor-years of nuclear plant operating experience for this time period is 251 reactor-years. By subtracting the fallures attributable to batteries or battery chargers from the total we can determine, as nearly as possible, a failure rate on the same bases as in References 1 and 2. Clearly the Reference 3 data are not as complete as the Reference 2 data. Nevertheless, if we assume the sane four inverters per plant and neglect the failures attributable to batteries or battery chargers, we arrive at the following fallure rates:

and

$$
\begin{aligned}
\lambda(\text { total } & =\frac{(181-29) \text { total fallures not battery-related }}{(4 \times 251 \text { inverter-years }) \times(8760 \mathrm{hr} / \mathrm{yr})} \\
& =1.73 \times 10^{-5} \text { failures } / \mathrm{hr} \\
& =0.151 \text { fallures } / \mathrm{yr}
\end{aligned}
$$

$$
\begin{aligned}
\lambda(\text { random }) & =\frac{0.67(181-29) \text { random failures not battery-related }}{(4 \times 251)(8760)} \\
& =1.16 \times 10^{-5} \text { failures } / \mathrm{hr} \\
& =0.101 \text { failures } / y r .
\end{aligned}
$$

\subsection{SUMMARY OF INVERTER RELIABILITY ESTIMATES BASED ON LERS}

In summarizing the inverter failure rates determined from References 1 , 2 , and 3 (see Table 6), we are concerned that the estimates be compared on the same basis. Inaccuracies are present due to 
The limited failure descriptions found in LERs,

The operating time of each plant,

The number of inverters in each plant,

The precise boundary of the inverter component, and

The number of plants considered in the analysis.

Lack of consistency in degree of detail and nomenclature used in LERs makes difficult their use for establishing rellability of a particular system or component.

Table 6. Inverter Reliability Estimates

\begin{tabular}{llccc}
\hline Source & $\begin{array}{c}\text { Time } \\
\text { Period }\end{array}$ & $\begin{array}{c}\text { Inverter-Yrs } \\
(4 \text { per plant })\end{array}$ & $\begin{array}{c}\text { No. Fallures } \\
\text { from All Causes }\end{array}$ & $\begin{array}{c}\text { Failure Rate } \\
\text { per Hour }\end{array}$ \\
\hline Ref. 1 & $1974-2 / 11 / 81$ & 388 & 46 & $1.35 \times 10^{-5}$ \\
Ref. 2 & $12 / 72-3 / 83$ & 2644 & 274 & $1.18 \times 10^{-5}$ \\
Ref. 3 & $1977-1981$ & 1004 & 152 & $1.73 \times 10^{-5}$ \\
\hline
\end{tabular}

The conclusion can be drawn from the Reference 2 and 3 studies that the principal cause of inverter failures is in random fallures of inverter components. Detalling of specific failures into subcomponent categories is not possible with any deg ree of reliability due to the inconsistencies in LERs mentioned above.

3. RELIABILITY OF LARGE LOAD COMMUTATED-INVERTER ADJUSTABLE-SPEED MOTOR DRIVES

One type of SSMC that has undergone major development is a system to provide variable frequency and voltage to an ac synchronous motor allowing motor operation over a wide speed range. Both General Electric and Westinghouse have developed this system, which uses load-commutated, phasecontrolled power converter technology to supply power to the stator winding of a synchronous motor. Other types of solid-state motor drive systems also are widely used in industry, including

dc drives,

Self-commutated-converters,

Forced-commutated inverters,

Modified Kraemer drives, and

Rectifier-inverter drives. 
These systems differ in their circuitry but all contain siniliar subcomponents.

In reviewing the extent of usage of large solid-state speed control systems, we have found none employed in current or planned nuclear power plants. However, based on current General Electric and Westinghouse views, the most probable candidate for use in nuclear plants is the load-comutated Inverter. General Electric, which has extensive experience with such inverters, has proposed to those utilities owning older BWR plants that they retrofit the main recirculating water pumps with load-conmutated inverter drive systems, eliminating the motor-generator drive systen currently in use. Although the variable-speed drive system for the recirculating vater pumps is not safety-related, pump speed control is necessary to maintain proper vold fraction in the reactor core with changing load. These pumps are generally $4000 \mathrm{hp}$ or more and are the only large variable-speed motor-driven loads in current light-water reactor plants. Westinghouse also has extensively developed load-commutated inverters; this developnent was described in our Interim Technical Letter Report No. 2 ("State-of-the-Art of Solid State Motor Controllers Usage in Varlous Industries Including Nuclear," April 1983), where the extensive use of load-commutated inverters by Westinghouse for induced-draft fans in fossil energy plants was discussed.

\subsection{GENERAL ELECTRIC DRIVE SYSTEM}

In proposing to utilities the use of load-commutated inverters in place of motor-generator sets to provide variable frequency/voltage to main recirculating water pumps in BWR plants, GE has made some claims for reliability of their drive system. The reliability estimates are based on experience with principal subcomponents including the thyristors, and have been determined by combining subcomponent failure rates to give an overall rate.

In Industrial applications, more so than in nuclear applications, an owner must be concerned with availability more than rellability. This is because avallability in a nuclear plant often is dictated more by the time required to perform specific regulatory functions following an equipnent failure, rather than the time required to repair. Because much of the downtime is attributable to functions not directly associated with actual repair, repalr tine loses much of its significance when nuclear jower plant fallures are considered. The relationship between avallability, reliability, and time to repair is as follows:

$$
\text { avallability }=\frac{1}{1+\frac{\mathrm{MTTR}}{\mathrm{MTBF}}},
$$

where MTTR is mean time to diagnose, repair, checkout and return to service, and MTBF is mean time between failures.

Load-commutated inverter systems give high availabilities because of the relatively long MTBF and, more importantly, the short MTTR compared to rotating equipment. MTTR for static electric systems is generally less than 8 hours. However, in a nuclear plant the MTTR may not necessarily be the "critical path" In a return to power operation.

In analyzing the reliability of large load-commutated inverters for 
synchronous motors [4], GE has divided the system into four broad categories of subcomponents and has assigned what they belleve to be realistic failure rates to each category. Subcomponent categories, failure rates, and avallabilities are shown in Table 7. Total systen avallability would be the product of the four subcomponent avallabllities shown in the table.

$$
\begin{aligned}
\text { Total availability } & =0.99917 \times 0.99975 \times 0.99993 \times 0.99997 \\
& =0.9988 .
\end{aligned}
$$

This avallability value suggest that this system will be operating or capable of operating $99.88 \%$ of the time or be out-of-service 10.5 hours per year. More meaningful to a nuclear plant operator is the fallure rate of the entire load-commutated inverter system, which is the sum of the subconponent failure rates ( $12.09 \times 10^{-5}$ fallures per hour). As can be seen, this value is wost heavily dependent on the fallure rate assigned to the power and control elect-onic subcomponent, the greatest source of fallures. The basis for the GE rellability values is GE's extensive experience with the conventional subcomponents (switchgear, transformers and reactors) and their carefully developed estimates of the solid-state device reliability.

Table 7. GE Load-Commutated-Inverter System Subcomponent Categorles, Failure Rates, and Availability

\begin{tabular}{lcccc}
\hline Subcomponent & $\begin{array}{c}\text { Failure Rate } \\
\text { per Hour }\end{array}$ & $\begin{array}{c}\text { MTBF } \\
\text { (hr) }\end{array}$ & $\begin{array}{c}\text { MTTR } \\
(\mathrm{hr})\end{array}$ & Avallabiltty * \\
\hline $\begin{array}{l}\text { Power and contro1 } \\
\text { electronics }\end{array}$ & $10.4 \times 10^{-5}$ & 9,578 & 8 & 0.99917 \\
$\begin{array}{l}\text { Switchgear } \\
\text { Transformers }\end{array}$ & $1.15 \times 10^{-5}$ & 86,956 & 21.6 & 0.99975 \\
dc reactors (filters) & $0.34 \times 10^{-5}$ & 294,118 & 20 & 0.99993 \\
& $0.16 \times 10^{-6}$ & 625,000 & 18 & 0.99997
\end{tabular}

* Percent of time; 1.e., a subcomponent with an avallability of 0.99917 would be operating or capable of operating $99.92 \%$ of the time.

The overall fallure rate, $12.09 \times 10^{-5}$ per hour, is conservative, based on GE data. A recent report by $G E$ on load-commutated inverters [5] gives a somewhat lower failure rate. The report states that the MTBF has been significantly improved by manufacturing and quality control techniques and that the calculated MTBF for a load-commutated inverter of the type discussed above is 15,000 to 20,000 hours (6.67 to $5 \times 10^{-5}$ fallures per hour). The avallabllity based on these fallure rates is $99.95 \%$, again due to the very short time for repair of these solld-state systems.

The rellability of load-commutated-inverter motor-drive systems can be Improved by redundancy in both the power and control circuits. Redundant thyristors are typically included in the power c1rcuit to provide rated power 
output with one thyristor device falled in any of the converter legs. Redundant control can be achieved, but often leads to complexities that promote additional fallures. A more favorable approach to redundancy is two completely independent power/control systems. This method, used by both GE and Westinghouse, simply parallels two six-pulse converter/inverter systens and uses their short-term emergency overload capabilities to achieve true redundancy.

\subsection{WESTINGHOUSE DRIVE SYSTEM}

The most significant development of load-commutated-inverter motor-c-ive systems has been conducted by Westinghouse and resulted in their "Varichron"* IIne of synchronous motor drives. Our Interim Technical Letter Report No. 2, ("State-of-the-Art of SolId State Motor Controllers Usage in Various Industries Including Nuclear," April 1983), lists Varichron systems currently in service and ordered-fifty-one systems totaling $331,900-h p$. The typical circuit used is very simflar to the General Electric designs and may be treated in common for purposes of rellability estimates. Of course, each inverter design, whether by Westinghouse or General Electric, is unique to its application but is sufficlently similar to the others to permit comparison.

Westinghouse has recelved operational reports on their Varichron units in service [6]. This type of customer report is difficult to use for establishing reliability values because of the bias placed on the report by the customer, whose Varichron unit may still be under warrantee. As an example, Toledo Edison, who has had four 3500-hp Varichron units in bofler induced-draft fan application since 1980, reported 24 failures in the first year of operation. Westinghouse estimates that two-thirds of these were due to operator er rors not related to equipment. The rellability assessments done by Westinghouse are used to satisfy customer requests or as a nanagerial decision tool to improve designs, and as sich are specific to particular designs. From data produced for a 1200-hp unit at Texas Eastman E11lot, Westinghouse determined that the probability of operating the unit $2-1 / 2$ years without a failure was 0.36 .

Complete fallure-rate estimates have been made by Westinghouse on typical large Varichron units based on published military specification data found in MIL-HDBK 217C and on some experience judgements. A typical Varichron failure rate, assuming no redundancy in a total 6- or 12-pulse drive system, was found to be 86.7 failures per $10^{6}$ hours or $8.67 \times 10^{-5}$ fallures/hour at $25^{\circ} \mathrm{C}$. Westinghouse stressed heavily the importance of low ambient temperature. They predicted that improved designs now in production will result in fallure rates of 2 to $5 \times 10^{-5}$ fa:lures/hour, with the higher value result of operation at $40^{\circ} \mathrm{C}$ rather than $25^{\circ} \mathrm{C}$ ambient temperature.

In estimating fallure rates, Westinghouse has used a widely accepted

\footnotetext{
* Reference to any specific commercial product, process, or service by trade name, trademark, manufacturer, or otherwise, does not necessarily constitute or imply its endorsement, recommendation, or favoring by the United States Government or any agency thereof.
} 
value for thyristor rellability [7]; the reported mean-time-between-failure for thyristors was 1000 years or $\sim 0.011 \times 10^{-5}$ failures/hour.

\section{HIGH-VOLTAGE DC TRANSMISSION-LINE CONVERTER RELIAB LLITY RELEVANT TO SSMC'S}

As is the case with solid-state vital-bus inverter systems in nuclear plants, experience with high-voltage solid-state dc transmission systems is a good source of rellability data on components and integrated systems similar to those found in SSMCs. Several modern high-voltage solid-state dc transmission systems have been built that

Rectify high-voltage ac at one end of a transmission line,

Transmit power at high-voltage dc to a distant receiving station, and

Invert the dc to ac ror local distribution.

The circuits used in these conversion systems are similar to those used in the large load-commutated inverters for adjustable-speed motor drives, although of much higher capacity. Six- or 12- pulse convertor systems using large thyristor banks and a dc-link interconnection typify the designs used. One could think of a solid-state adjustable-frequency synchronous motor-drive system as a very short dc transmission-line conversion system.

At the end of 1980 , worldwide there were $10 \mathrm{high}$-voltage dc transmission systems using solid-state conversion of ac to dc to ac. The dc transmission voltages range from 80 to $535 \mathrm{kV}$ and power from 320 to $1920 \mathrm{MW}$. The reliability performance of these systems has been reported consistently by the utilities to Working Group 04 of Study Committee No. 14 of CIGRE and summarized every two or three years at ar International Conference on Large High-Voltage Electric Systems. The latest report [8] has been selected as a source of reliability information pertinent to SSMCs. In the report, emphasis is placed on the availability of the transmission line rather than failure rates of components, and a distinction is made between failures causing forced outages and those not causing outages. These systems contain very large numbers of thyristors in series, where individual failed thyristors are replaced only during scheduled malntenance outages. For the reasons stated in Section 3.1, we will concern ourselves more with reliability than availability--chlefly, the rellability of families of equipment that cause forced outages. We believe these results are directly applicable to the same families of equipment in SSMCs.

Table 8 lists the 10 high-voltage dc (HVDC) solid-state transmission systems in world service in 1979-1980. The magnitude of these systems is reflected in their total capacity (6606 MW) and in the total number of power thyristors used $(74,680)$. Data given In Reference 8 allow categorization of failures into families of equipment that typify SSMCs as well as HVDC systems. In Table 9, the $10 \mathrm{HVDC}$ systems are listed again, together with the numbers of fallures occurring in 5 categories of equipment. 
Table 8. Worldwide Solid-State High-Voltage DC Transmission Systems, 1979-1980

\begin{tabular}{|c|c|c|c|c|c|}
\hline System (Country) & $\begin{array}{l}\text { Year of } \\
\text { Commission }\end{array}$ & $\begin{array}{l}\text { Capacity } \\
\text { (MW) }\end{array}$ & $\begin{array}{l}\text { Type of } \\
\text { Converter }\end{array}$ & $\begin{array}{l}\text { Total No. } \\
\text { of Thyristors }\end{array}$ & $\begin{array}{l}\text { Operating Time } \\
\text { in } 1979-80(\mathrm{hr})\end{array}$ \\
\hline Eel Rfver (Canada) & 1972 & 350 & 12-pulse & 9,600 & 17,257 \\
\hline Skagerrak (Denmark) & $1976-77$ & 500 & 12-pulse & 6,912 & 13,140 \\
\hline Hamil (USA) & 1977 & 110 & 12-pulse & 2,880 & 13,841 \\
\hline Cahora-Bassa (S. Africa) & $1977-79$ & 1920 & 6-pulse & 22,656 & 10,161 \\
\hline Vancouver (Canada) & $1977-79$ & 476 & 6-pulse & 8,640 & 14,804 \\
\hline Square Butte (USA) & 1977 & 550 & 12-pulse & 6,912 & 16,732 \\
\hline Shin-Shinano (Japan) & 1977 & 300 & 6-pulse & 5,184 & 16,469 \\
\hline Nelson River (Canada) & 1978 & 1000 & 12-pulse & 9,216 & 5,431 \\
\hline Hokka1do-Honshu (Japan) & $1979-80$ & 300 & - & 2,712 & 1,664 \\
\hline \multirow[t]{2}{*}{ CU (USA) } & 1979 & 1100 & - & 8,640 & 7,358 \\
\hline & & $\overline{6606}$ & & 74,680 & 116,857 \\
\hline
\end{tabular}


Table 9. Component Failures Causing HVDC Systen Outages in 1979-1980

\begin{tabular}{|c|c|c|c|c|c|c|}
\hline \multirow[b]{2}{*}{ System } & \multicolumn{6}{|c|}{ Number of Componen ${ }^{*}$ Failures } \\
\hline & $A C-E$ & Thyristors & $\mathrm{C} \& \mathrm{P}$ & $D C-E$ & Other & Total \\
\hline Eel RIver & 28 & 3 & 36 & 1 & 10 & 78 \\
\hline Skagerrak & 17 & 1 & 15 & 3 & 1 & 37 \\
\hline Hamil & 3 & 1 & 0 & I & 1 & 6 \\
\hline Cahora-Bassa & 38 & 0 & 170 & 13 & 10 & 231 \\
\hline Vancouver & 18 & 3 & 6 & 26 & 13 & 66 \\
\hline Square Butte & 19 & 2 & 32 & 5 & 19 & 77 \\
\hline Shin-Shinano & 0 & 0 & 2 & 0 & 0 & 2 \\
\hline Nelson river & 19 & 0 & 22 & 23 & 21 & 85 \\
\hline Hokkaido-Honshu & 0 & 0 & 1 & 0 & 1 & 2 \\
\hline CU & 5 & 2 & 2 & 2 & 3 & 14 \\
\hline Tolal & 147 & 12 & $\overline{286}$ & 74 & 79 & 598 \\
\hline
\end{tabular}

${ }^{*} \mathrm{AC}-\mathrm{E}$ (ac and auxiliary equipment) - all ac power equipment for the HVDC station, including converter trausformers, conventional ac protection, and ac auxiliary equipment.

Thyristors - the complete array forming the converter bridge, lncluding all auxiliaries and components integral with the thyristors and part of the array. C\&P (control and protection equipment) - equipment used for the control, monitoring, and protection of each HVDC station, except the corventional type, which is included in "ac and auxiliary equipment."

DC-E (primary dc equipment) - dc equipment including dc reactor, dc switchgear, reactor surge arresters, dc filters, earth electrodes, etc.

other - unknown and operator errors.

Table 9 indicates a high total number of fallures (598). However, as stated earlier, the operating utilities are concerned mainly with outage duration, not with numbers of failures. The 598 failures caused only 1,160 hours of downtime out of a total operating time of 116,857 hours (from Table 8 ), for an unavailability of about $1 \%$. This is an acceptable unavailability for a HVDC transmission system compared to the normal scheduled maintenance downtime of $1-5 \%$.

Of greatest relevance to SSMCs is the reliability of the thyristors in these HVDC systems. The surprisingly low total of only 12 thyristor fallures 
out of 74,680 thyristors in 116,857 operating hours is deceptive. HVDC systems are designed such that from one to four thyristors are connected in parallel to form a thyristor "leve1," referring to voltage level. A very large number of levels in serles constitute the total solld-state "valve." For a thyristor failure to cause an outage and thus qualify for Table 9 , it must cause, by itself or in combination with others in series, $a$ loss of the entire valve. This is unlikely because HVDC systens are conservatively designed to allow operation with a number of thyristors falled by shorting, awaiting a scheduled outage to be routinely replaced. One of the reasons for such thorough reporting of HVDC systen fallures is to study thyristor rellability in an effort to optimize the number of excess levels of thyristors in a bridge leg so that prolonged operation with falled thyristors can take place with minimum likelihood of total valve failure.

A direct calculation of the fallure rates $(\lambda)$ of the five categories of equipment that cause outages can be made using Tables 8 and 9. We should be cautious in comparing these fallure rates with those given in Section 2 of this report. We are dealing with a very swall number or units (10), individually much more complex than an ac vital-bus inverter.

Failure rates of the five equipment categorles (see Table 9) are:

$A C-E$ (ac and auxiliary equipment)

$$
\lambda_{A C-E}=\frac{147 \text { (failures) }}{10 \text { (no. of units) } \times 116857 \text { (hrs) }}=12.6 \times 10^{-5} \text { fallures } / \mathrm{hr} \text {, }
$$

Thyristors (total valve fallure)

$$
\lambda_{\text {thy }}=\frac{12}{10 \times 116857}=1.03 \times 10^{-5} \text { fallures } / \mathrm{hr},
$$

$C$ and $P$ (control and protection equipment)

$$
\lambda_{C \text { and } P}=\frac{286}{10 \times 116857}=24.5 \times 10^{-5} \text { failures } / \mathrm{hr},
$$

DC-E (primary dc equipment)

$$
\lambda_{\mathrm{DC}-\mathrm{E}}=\frac{74}{10 \times 116857}=6.33 \times 10^{-5} \text { fallures } / \mathrm{hr} \text {, and }
$$

Other

$$
\lambda_{0}=\frac{79}{10 \times 116857}=6.76 \times 10^{-5} \text { fallures } / \mathrm{hr} .
$$

The total fallure rate for an HVDC system resulting in an outage is $51.2 \times 10^{-5}$ fallures/hour.

Data on numbers of level fallures not necessarily causing outages are given in Reference 8. By assuming that each level fallure is caused by one thyristor fallure regardless of the number of parallel thyristors in a level, one can estimate the Individual thyristor fallure rate, knowing the operating, time and number of thyristors from Table 8. In Table 10, the number of levels and corresponding number of thyristors for each system, number of falled levels, and resulting thyristor fallure rates are given. 
HVDC systems occasionally have failures involving many levels of thyristors that are not due to thyristor defects. This occurred in the 197980 perlod at Skagerrak and $\mathrm{CU}$. The multiple fallures are not included in Table 10 . The average failure rate for thyristors in HVDC in 1979-80 is 0.025 $\times 10^{-5}$ per hour, or about $0.22 \%$ per year.

Table 10. Thyristor Failure Rates in HVDC Systems

\begin{tabular}{lcccc}
\hline & $\begin{array}{c}\text { Total } \\
\text { Levels }\end{array}$ & $\begin{array}{c}\text { Total } \\
\text { Thyristors }\end{array}$ & $\begin{array}{c}\text { Falled } \\
\text { Levels, } \\
1979-80\end{array}$ & $\begin{array}{c}\text { Thyristor } \\
\text { Fallure Rate } \\
\text { per Hour }\end{array}$ \\
\hline Eel River & 2,400 & 9,600 & 69 & $0.042 \times 10^{-5}$ \\
Skagerrak & 6,912 & 6,912 & 16 & $0.018 \times 10^{-5}$ \\
Hamil & 720 & 2,880 & 12 & $0.030 \times 10^{-5}$ \\
Cahora-Bassa & 11,328 & 22,656 & 24 & $0.010 \times 10^{-5}$ \\
Vancouver & 4,320 & 8,640 & 23 & $0.018 \times 10^{-5}$ \\
Square ButLe & 6,912 & 6,912 & 20 & $0.018 \times 10^{-5}$ \\
S' in-Shinano & 3,744 & 5,184 & 3 & $0.004 \times 10^{-5}$ \\
Nelson River & 4,608 & 9,216 & 15 & $0.030 \times 10^{-5}$ \\
Hokkaido-Honshu & 2,712 & 2,712 & 0 & 0 \\
CU & 8,640 & 8,640 & 52 & $0.082 \times 10^{-5}$ \\
& & & &
\end{tabular}

\section{SUMMARY}

We should be very cautious in comparing solid-state-system fallure rates derived from systems vastly different in size and complexity, or between systems meeting different objectives. Table 11 shows the variance in failure rates between the systems discussed in this report. The conclusion that larger systems are less reliable than smaller systems is not unexpected and is reflected in the fallure rates.

In the case of load-commutated synchronous motor drives, loss of function can be significantly improved by redundancy, as is already done for ac vitalbus inverters. 
Table 11. Sumary of Solid-State Systen Rellability

\begin{tabular}{|c|c|c|c|}
\hline Source & Type of System & $\begin{array}{l}\text { Basis } \\
\text { for } \\
\text { Deternination }\end{array}$ & $\begin{array}{l}\text { Systen } \\
\text { Fallures } \\
\text { per Hour }\end{array}$ \\
\hline Ref. 1 & $\begin{array}{l}\text { Nuclear plant ac vital- } \\
\text { bus inverters }\end{array}$ & 398 inverter-years & $1.35 \times 10^{-5}$ \\
\hline Ref . 2 & $\begin{array}{l}\text { Nuclear plant ac vital- } \\
\text { bus inverters }\end{array}$ & 2644 inverter-years & $1.18 \times 10^{-5}$ \\
\hline Ref. 3 & $\begin{array}{l}\text { Nuclear plant I\&C power } \\
\text { systems less batteries }\end{array}$ & 1004 Inverter-years & $1.73 \times 10^{-5}$ \\
\hline $\operatorname{Ref.} 4$ & $\begin{array}{l}\text { GE load-commutated } \\
\text { adjustable-speed drives } \\
\text { for synchronous motors }\end{array}$ & $\begin{array}{l}\text { Calculation } \\
\text { from component } \\
\text { experlence }\end{array}$ & $12.09 \times 10^{-5}$ \\
\hline $\operatorname{Ref} \cdot 5$ & $\begin{array}{l}\text { GE load-commutated } \\
\text { adjustable-speed drives } \\
\text { for synchronous motors }\end{array}$ & $\begin{array}{l}\text { Calculation } \\
\text { from component } \\
\text { experience }\end{array}$ & 5 to $6.67 \times 10^{-5}$ \\
\hline Ref. 8 & $\begin{array}{l}\text { World-wide HVDC trans- } \\
\text { mission-line converters }\end{array}$ & 20 converter-years & $51.2 \times 10^{-5}$ \\
\hline
\end{tabular}


REFERENCES

1. NRC Letter, J.E. Knight, Operating Experience Evaluation Branch, DST/NRR, to E. :densam, Acting Chlef, Operating Experience Evaluation Branch, DST/NRR, subject, "Inverter Failures," March 19, 1981.

2. G. Bozoki and I.A. Papazoglou, "Analysis of Inverter callues in Nuclear Power Plants," Dept. of Nuclear Energy, Brookhayen Nat Ional Labortory, unpublished draft report (April 1983).

3. J.S. Bhatti, "Investigation of Fallures In I\&C Power Supply Hardware" by International Engineering Co., Inc., for the Naclear Safety Analysis Center, NSAC-44, (Dec. 1981 ).

4. Personal Communication with Herbert W. Weiss, General Electric Co., Drive Systems Dept., Salem, Va, June 24, 1983.

5. Herbert $w$. Welss, "Power Transmission to Synchronous Machines for Adjustable-Speed Pump and Compressor Drive Systems," IEEE 29th Annual Petroleum and Chemical Industry Conference Record, August 30-Septenber 1, 1982, St. Louis, Mo.

6. Personal communication with David Hawkins and Neville Jacobs, Westinghouse Electric Co., Quality Assurance Dept., Buffalo, N. Y., July 12, 1983.

7. L.F. Stringer, "Synchronous Motor Adjust ble Frequency Drive Systems for Large Mechanica1-Draft Fans," Pro. An. Power Conf., Vo1. 42, Apri1 21, 1980.

8. J. Knudsen and P.F. Albrecht, "A Survey of the Reliability of HVDC Systems Throughout the World During 1979-80," CIGRE International Conference on Large High Vollage Electric System, Sept. 1-9, 1982, Report No. 14-06. 
Distribution for ANL-CT-83-6

Internal:

R. A. Jaross (10)

S. K. Zussman

E. R. Koeh1

T. P. Mulcahey

G. S. Rosenberg

ANL Patent Dept.

ANL Contract File

R. S. Zeno

ANI Libraries (2)

TIS Files (6)

\section{External:}

DOE-TIC (2)

Manager, Chicago Operations Office, DOE

B. Marcus, Div . of Facility Operations, USNRC, Washington (3)

Components Technology Division Review Committee:

D. J. Anthony, General Electric Co., Schenectady

A. A. Bishop, U. Pittsburgh

B. A. Boley, Northwestern U.

F. W. Buckman, Consumers Power Co.

R. Cohen, Purdue U.

E. E. Unga:, Bolt Beranek and Newman Inc., Cambirdge, Mass.

J. Weisman, U. Cincinnati 